\title{
Spirulina-Enriched Pasta as Functional Food Rich in Protein and Antioxidant
}

\author{
Ahmed Hussein ${ }^{1}$ (D) , Gamil Ibrahim 2 ${ }^{\text {(D) }}$, Mohie Kamil ${ }^{1}$ (D), Marwa El-Shamarka ${ }^{3}$ (D), \\ Sayed Mostafa 1(D), Doha Mohamed 4,* (D)
}

1 Food Technology Dept., National Research Centre, Dokki 12622, Cairo, Egypt; said22220@yahoo.com (A.H.); researchteammmk@hotmail.com (M.K.); abnody.sayed@gmail.com (S.M.);

2 Chemistry of Aroma and Flavor Dept., National Research Centre, Dokki 12622, Cairo, Egypt; gamilemad2000@gmail.com;

3 Toxicology and Narcotics Dept., National Research Centre, Dokki 12622, Cairo, Egypt; marwaelshamarka@gmail.com (M.E-S.);

4 Nutrition and Food Sciences Dept., National Research Centre, Dokki 12622, Cairo, Egypt; dohamohamed@yahoo.com (D.M.);

* Correspondence: dohamohamed@yahoo.com;

Scopus Author ID 8685446400

Received: 6.02.2021; Revised: 6.03.2021; Accepted: 10.03.2021; Published: 31.03.2021

\begin{abstract}
Functional foods are considered foods that have a beneficial impact when ingestion. The present work aims to prepare functional food in the form of pasta rich in antioxidants and protein by enrichment with different Spirulina levels (SP). To achieve this aim, acute and chronic toxicity of SP were evaluated in experimental animals. Antioxidant activity, total phenolic compound content, physicochemical, rheological, and sensorial parameters were evaluated in pasta samples. Volatile compounds were investigated in pasta samples using SPME-GC-MS. Spirulina indicated complete safety in acute and chronic toxicity studies. Protein content in pasta increased with the increment of SP. Rheological parameters, color, and cooking quality were increased following SP level while; dough stability was decreased. Sensory evaluation of pasta samples was acceptable up to 5\% SP. Total phenolic compound content was increased in pasta with increasing S SP's level and reaches its maximum value at level 10\% SP (3.12 mg GAE/g). Antioxidant activity was reduced in cooked pasta compared to uncooked. Twenty-five volatile compounds were identified in fresh pasta samples $(0$ \& $2.5 \% \mathrm{SP})$. Hexanal and 2-pentylfuran were the highest volatile compounds in pasta samples. Spirulina is completely safe and could be used in the preparation of functional foods. Spirulina-enriched pasta is a rich source of protein and antioxidants. The enrichment of pasta caused a reduction in sensory scores with an increase in the addition level. This reduction may be due to the low concentration of 2pentylfuran and hexanal as flavor compounds.
\end{abstract}

Keywords: Spirulina; acute toxicity; chronic toxicity; pasta; phenolic compounds; volatile compounds.

(C) 2021 by the authors. This article is an open-access article distributed under the terms and conditions of the Creative Commons Attribution (CC BY) license (https://creativecommons.org/licenses/by/4.0/).

\section{Introduction}

Spirulina platensis (SP) is blue-green algae that belong to cyanobacteria [1]. SP is a rich protein source (46-63\%), essential fatty acids, vitamins, and minerals. The protein of SP contains essential amino acids, which can be compared with standard proteins such as meat, egg, and milk. SP protein is superior in comparison with vegetable proteins [2,3]. The amino acid composition of SP protein is balanced, and their concentrations are close to those required by WHO and FAO [4]. Also, SP is considered as a valuable source of antioxidants such as 
phycocyanin, carotenoids, and phenolic compounds [5]. All these bioactive compounds in SP reduced the risk of chronic diseases such as cardiovascular diseases, inflammatory disease, type-2 diabetes, and cancer [6]. Around the world, SP is one of the top trends in the food industry [7]. It's a superfood ingredient, which may be used for the preparation of functional foods. Many food products containing SP are produced daily, such as bread, biscuits, and pasta [8]. Till now, Egyptian Food Markets do not contain any food product contains SP. So the authors of the present work decided to produce functional food containing Spirulina in the form of pasta. Pasta is considered a basic popular and favorite food for all age groups produced from cereals [9]. Pasta contains low protein, so the enhancement of protein content of pasta through enrichment by SP is a very important approach to solve the problem of protein deficiency in the developing countries for providing Food Markets with a food source that is popular and affordable for all ages and has high economic value and achieves sustainable development. Flavor compounds are responsible for the quality of cooking products and could be used as informative about the quality of raw materials and processing conditions [10, 11]. Several studies on the analysis of volatile profiles in cooked pasta obtained by various durum wheat species exhibited significant influences on aroma compounds. Also, the type of semolina obtained after toasted the grains of durum wheat had a noticeable effect on the formation of volatile compounds in cooked pasta $[12,13]$. So the present research aims to produce Spirulinaenriched pasta as functional food high in protein and antioxidants. To achieve this goal, acute and chronic toxicity studies must be evaluated in Spirulina platensis powder before incorporating it in the pasta preparation. The physicochemical, rheological, and sensorial parameters were evaluated in the prepared pasta. The antioxidant activity and total phenolic compound content of cooked and uncooked pasta were assessed. The effect of enrichment of pasta with SP on volatile compounds was investigated using SPME-GC-MS. To the best of our knowledge there is no studies have been performed to reveal the effect of enrichment of pasta by Spirulina on volatile compounds after cooking.

\section{Materials and Methods}

\subsection{Animals.}

Male Sprague Dawley rats 100-110 g was used in studying the chronic toxicity study. Animals were kept individually in stainless steel cages at room temperature of $25 \pm 2^{\circ} \mathrm{C}$ and relative humidity of about 55\%; water and food were given ad-libtium. Adult normal male and female albino mice of 21-25 g body weight were used in acute oral toxicity.

Wheat flour (72\% extraction rate) (WF) was purchased from the North Cairo Flour Mills Company, Egypt, and salt was purchased from local markets in Giza, Egypt. All chemicals were analytical grade. Spirulina microalgae powder (SP) was obtained from Nourelhooda Co., 48 Fared Semeika St., El-Nozha, Cairo, Egypt. Spirulina powder was kept in cool and dry conditions in polypropylene bag with an aluminum layer until pasta processing.

\subsection{Acute oral lethal toxicity of Spirulina.}

An acute lethal toxicity test of Spirulina algae was carried out according to Goodman et al. [14]. Acute oral toxicity test was carried out according to the procedure and methods of Food Safety Toxicological Assessment. After fasting for $4 \mathrm{~h}$, thirty-six mice (18 male \& 18 female) were divided into 6 groups that received orally a single dose of $1,2,4,6,8,10 \mathrm{~g} / \mathrm{kg}$ $\mathrm{BW}$ of the algae extract. The animals were monitored individually for changes in general 
behavior, any signs of toxic symptoms and mortality at $30 \mathrm{~min}, 1 \mathrm{~h}, 2 \mathrm{~h}, 4 \mathrm{~h}, 24 \mathrm{~h}$ after administration, and at least once daily for the next 10 days. Bodyweight and food intake of each animal were recorded before treatment and on the tenth day.

\subsection{Chronic toxicity of Spirulina.}

Eighteen male rats were divided into three groups. Group one served as normal control where rats received the vehicle, while group two and three were received low and a high dose of Spirulina 250 and $500 \mathrm{mg} / \mathrm{kg}$ rat BW/day for a month as 1/20and 1/40 from the highest dose used in the acute toxicity. During the study, rats were fed on a standard chow diet. At the end of the experiment, rats were weighed, and the body weight gain was calculated. Blood samples were collected from all rats after an overnight fast in tubes containing heparin. The percent of packed cell volume (PCV) was determined, and blood hemoglobin (Hb) was determined in blood samples. Plasma was separated for determination of alanine aminotransferase (ALT), and aspartate aminotransferase (AST) was determined as an indicator of liver function, while creatinine and urea were determined as an indicator of kidney function. Plasma total protein and albumin were evaluated as an indicator of nutritional status and an extra liver function indicator. Plasma globulin and the ratio of albumin to globulin (A/G ratio) were calculated. Also, plasma total cholesterol and triglycerides, high-density lipoprotein-cholesterol (HDLCh) were estimated, while low-density lipoprotein-cholesterol (LDL-Ch) was calculated. All biochemical parameters were determined using Erba Mannheim diagnostic Kit. For histopathological examination, part of liver and kidney were removed, placed in 10\% formaldehyde, dehydrated in graded alcohol, and embedded in paraffin. Fine sections were prepared, mounted on glass slides, and counter-stained with hematoxylin and eosin for light microscopic analysis [15]. The relative weight of liver and kidney of each animal was calculated as follows: Relative liver or weight $=$ Absolute liver or kidney weight $(\mathrm{g}) \times 100 /$ final body weight (g). According to the recommendations of the National Institutes of Health Guide for Care and Use of Laboratory Animals (Publication No. 85-23, revised 1985) and the Ethics Committee of the National Research Centre, Cairo, Egypt, animal procedures were performed.

\subsection{Preparation of wheat flour (WF) and SP mixtures.}

Wheat flour was well blended with SP to produce individual mixtures containing 0, 2.5, 5.0, 7.5, and $10 \%$ SP. All samples were stored in airtight containers and kept at $5-7^{\circ} \mathrm{C}$ till used.

\subsection{Proximate composition.}

Moisture, ash, fat, and protein contents of WF, SP, and pasta samples were determined according to AACC [16]. Total carbohydrates were calculated by difference. Mineral content (Ca, P, K, Fe, and Mn) in WF, SP, and pasta were determined according to the method described by Chapman \& Pratt [17]. The amino acid profile of WF, SP and pasta samples was evaluated according to the method of AOAC [18]. Amino acids were expressed as $\mathrm{g} / 100 \mathrm{~g}$ protein on a dry weight basis.

\subsection{Rheological properties.}

Rheological properties of dough's were evaluated using farinograph parameters according to AACC [16]. 
2.7. Color, cooking quality, and texture properties of pasta.

$\mathrm{L}^{*}, \mathrm{a}^{*}$, and $\mathrm{b}^{*}$ color parameters were measured in pasta samples (raw and cooked) using Hunter colorimeter (Hunter Associates Lab Inc. (Model No: LabScan XE, USA). The cooking quality of pasta was carried out according to AACC [19] method by measuring the increases in weight, volume, and cooking loss after cooking Cooking quality of pasta was carried out by measuring the increases in weight, volume, and cooking loss after cooking according to the methods of AACC [19]. Textural properties of uncooked and cooked pasta samples during rupture were evaluated using texturometer, Brookfield model-CT3-10 kg, USA, equipped with Fixture (TA-SBA). Texture properties were conducted to determine the hardness, deformation at hardness, hardness work, load at target, deformation at target, peak stress, fracturability, and fracture load drop-off. Trigger load and test speed were $9.00 \mathrm{~N}$ and $2.5 \mathrm{~mm} / \mathrm{sec}$, respectively. Pasta dimensions were as follows: shape: cylinder; length: $30 \mathrm{~mm}$; diameter $50 \mathrm{~mm}$.

\subsection{Sensory evaluation of pasta.}

Pasta samples were cooked in distilled water to optimum cooking time, and after draining for $2 \mathrm{~min}$ and then served to the panelists. The sensory test panel consisted of seven panelists who were trained academic staff. The panelists evaluated the products for color, flavor, mouthfeel, elasticity, and overall acceptability using a 10-point hedonic scale ranging from 10-5 (like extremely) to 4-1 (dislike extremely) for each sensory characteristic [20].

2.9. Determination of total phenolic content and antioxidant activity of Spirulina and pasta samples.

Spirulina and different pasta samples were extracted using the method adopted from Abu-Bakar et al. [21]. The total phenolics content was determined using the Folin-Ciocalteu reagent according to the method of Abu-Bakar et al. [21]. The total phenolic content was calculated and expressed as gallic acid equivalents per gram (mgGAE/g).

\subsubsection{DPPH free radical scavenging activity.}

The hydrogen atom or electron-donation ability of Spirulina and different pasta samples was measured from the bleaching of a purple-colored methanol solution of DPPH [22]. The antioxidant activity of the extracts, based on the scavenging activity of the stable 1,1'-diphenyl2- picrylhydrazyl (DPPH) free radical, was determined by the method described by Braca et al. [23]. Methanolic extract of Spirulina and different pasta samples $(0.5 \mathrm{ml})$ was added to 3 $\mathrm{ml}$ of a $0.001 \mathrm{M} \mathrm{DPPH}$ in methanol, and the absorbance was determined at $517 \mathrm{~nm}$.

\subsubsection{Reducing power assay.}

The reducing power of the sample was determined by the method described by Oyaizu [24]. An aliquot of each sample $(500 \mu 1)$ was mixed with $500 \mu 1$ sodium phosphate buffer $(0.2$ $\mathrm{M}, \mathrm{pH}$ 6.6) and $500 \mu \mathrm{l}$ of $1 \%$ potassium ferricyanide, followed by incubation at $50{ }^{\circ} \mathrm{C}$ for 20 min. After the addition of $500 \mu 1$ of $10 \%$ TCA, the mixture was centrifuged at $12,000 x g$ for 10 min, and the supernatant $(1.0 \mathrm{~mL})$ was incubated in the presence of $1.0 \mathrm{~mL}$ of distilled water, and $200 \mu \mathrm{l}$ of $0.1 \%$ ferric chloride for $10 \mathrm{~min}$ and the absorbance was read at $700 \mathrm{~nm}$. Trolox (6-hy-droxy-2,5,7,8-tetramethylchloromane-2-carboxylicacid; Sigma-Aldrich Chemical) was 
used to construct calibration curves, and all the results were expressed as Trolox equivalent (in micromoles of Trolox per gram of sample).

\subsection{Volatile compounds.}

The analysis of volatile compounds in control fresh cooked pasta and selected treatment $(2.5 \%)$ samples were carried out using the static headspace solid-phase micro-extraction (HS)SPME technique was adopted. The extraction protocol employed5 $\mathrm{g}$ samples, without the addition of water, subjected to solid-phase micro-extraction using a $50 / 30 \mathrm{~mm}$ DVB/Carboxen/PDMS Stable Flex fiber directly inserted in the headspace in a $40 \mathrm{~mL}$ amber vial with cap and PTFE/Silicon septa (Supelco, Co., Bellefonte, PA) for $24 \mathrm{~h}$. The vials were maintained at $30 \pm 0.1{ }^{\circ} \mathrm{C}$ in a water bath. After sampling, the SPME device was placed immediately into a splitless mode injection port of the GC-MS instrument. The scan range was from 15 to $300 \mathrm{amu}$ and recorded at $4.86 \mathrm{scan} / \mathrm{s}$. The volatile compounds were separated using a capillary column HP-Innowaxa $60 \mathrm{~m} \mathrm{X} 0.25 \mathrm{~mm}$ (i.d.), film thickness $0.25 \mathrm{~mm}$ HP-5 ms column connected with the Agilent Technologies (Palo Alto, CA) equipped with $5977 \mathrm{MS}$ detector. The volatile compounds adsorbed to the SPME fiber were thermally desorbed at 230 ${ }^{\circ} \mathrm{C}$ for $15 \mathrm{~min}$. Helium was used as the carrier gas at a constant flow rate of $1 \mathrm{~mL} / \mathrm{min}$. The oven temperature, $40{ }^{\circ} \mathrm{C}$, was held for $1 \mathrm{~min}$ and then increased $3^{\circ} \mathrm{C} / \mathrm{min}$ to $180^{\circ} \mathrm{C}$ and held for $1 \mathrm{~min}$. Subsequently, the temperature was increased to $240^{\circ} \mathrm{C}$ with a rate of $10^{\circ} \mathrm{C} / \mathrm{min}$ and held for 5 min. The transfer line and ion source temperature were $250^{\circ} \mathrm{C}$ and $230^{\circ} \mathrm{C}$, respectively. Volatile compounds were identified by comparing their spectra with those contained in the NIST98 and Wiley Mass Spectral Databases. The linear retention index (RI) values for unknowns were determined based on retention time data obtained by analyzing a series of normal alkanes $\left(\mathrm{C}_{6}\right.$ $\left.\mathrm{C}_{22}\right)[25]$.

\subsection{Statistical analysis.}

One-way analysis of variance ANOVA followed by Duncan's test was used for the analysis of animal experiments results (Mean \pm SE). SAS Systems for Windows software, version 6.12 TS020 (SAS, Statistical Analysis System, Institute Inc., Cary, NC, 1996) were used for statistical analysis of all results of pasta and raw materials results. We performed an analysis of variance (ANOVA) and the least significant difference (LSD) test $(\mathrm{P}<0.05)$ to determine significant differences between the treatment means.

\section{Results and Discussion}

\subsection{Acute toxicity of Spirulina.}

Acute lethal toxicity test revealed that Spirulina algae were completely safe up to the highest dose used $10 \mathrm{~g} / \mathrm{kg}$ mice bodyweight that is corresponding to $77.5 \mathrm{~g} / 70 \mathrm{~kg}$ man body weight human [26]. No mortality, no physical appearance abnormalities, no changes in behavioral patterns, and no signs of toxicity were observed in all treatment groups during 10 days after oral administration. Furthermore, the mean body weight, food consumption, and food utilization rate of mice in all treatment groups showed non-significant differences. The median lethal dose (LD50) of Spirulina is $>10 \mathrm{~g} / \mathrm{kg} \mathrm{BW}$. 


\subsection{Chronic toxicity of Spirulina.}

The nutritional and biochemical parameters of all the experimental groups are presented in Table1. Oral administration of Spirulina powder in low or high dose showed non-significant changes in final body weight, liver and kidney relative weight compared with a normal control group. As noticed from table 1, rats that received a low or high oral dose of Spirulina showed non-significant changes in all the studied biochemical parameters compared with normal control rats. Blood Hemoglobin and PCV levels represented in table 1 revealed that Spirulina administration in low and high doses was similar in the normal control group. Plasma lipid profile (T-Ch, TG, HDL-Ch\& LDL-Ch) of rats given Spirulina appeared normal style c compared to the control group. Plasma levels of protein, albumin, globulin, and A/G ratio appeared similar in all groups without any changes. Blood sugars showed non-significant changes between all the studied groups. This means that Spirulina didn't induce any elevation in blood glucose. Liver (AST \& ALT) and kidney (urea \& creatinine) functions of all studied groups appeared in normal levels compared with normal rats. Histopathology of liver and kidney tissues is presented in Figure 1. The liver of all rat groups showed normal parenchyma of hepatic cords, blood sinusoids, and portal areas. Histopathological examination of sections from rat kidneys of the different group's was free from any significant pathological changes. The present results are in agreement with the previous study by Athane'et al. [27]. Previously Gutiérrez-Salmeán et al. [28]proved that Spirulina had not induced acute or chronic toxicities in experimental animals. From the observed results in the present study and the results of previous studies [27, 28], we can decide that Spirulina is completely safe for use as a functional food ingredient for human consumption.

Table 1. Nutritional and biochemical parameters of different groups.

\begin{tabular}{|c|c|c|c|}
\hline Parameters & Normal & $\begin{array}{c}\text { Spirulina low dose (250 } \\
\mathrm{mg} / \mathrm{kg})\end{array}$ & $\begin{array}{c}\text { Spirulina high dose (500 } \\
\mathrm{mg} / \mathrm{kg})\end{array}$ \\
\hline Initial body weight $(\mathrm{g})$ & $103^{\mathrm{a}} \pm 1.632$ & $103.5^{\mathrm{a}} \pm 1.586$ & $103.2^{\mathrm{a}} \pm 1.759$ \\
\hline Final body weight $(\mathrm{g})$ & $136.8^{\mathrm{a}} \pm 1.621$ & $137.2^{\mathrm{a}} \pm 1.137$ & $137.7^{\mathrm{a}} \pm 0.954$ \\
\hline Body weight gain $(\mathrm{g})$ & $33.80^{\mathrm{a}} \pm 1.887$ & $34.0^{\mathrm{a}} \pm 2.463$ & $34.2^{\mathrm{a}} \pm 2.329$ \\
\hline Liver \% & $3.1^{\mathrm{a}} \pm 0.041$ & $3.1^{\mathrm{a}} \pm 0.082$ & $3.1^{\mathrm{a}} \pm 0.049$ \\
\hline Kidney \% & $0.672^{\mathrm{a}} \pm 0.027$ & $0.659^{\mathrm{a}} \pm 0.025$ & $0.673^{\mathrm{a}} \pm 0.018$ \\
\hline $\mathrm{Hb}(\mathrm{g} / \mathrm{dl})$ & $14.5^{\mathrm{a}} \pm 0.101$ & $14.6^{\mathrm{a}} \pm 0.145$ & $14.7^{\mathrm{a}} \pm 0.111$ \\
\hline PCV \% & $34.5^{\mathrm{a}} \pm 0.764$ & $34.7^{\mathrm{a}} \pm 0.667$ & $34.8^{\mathrm{a}} \pm 0.703$ \\
\hline $\mathrm{T}-\mathrm{Ch}(\mathrm{mg} / \mathrm{dl})$ & $71.5^{\mathrm{a}} \pm 1.175$ & $71.7^{\mathrm{a}} \pm 1.333$ & $71.2^{\mathrm{a}} \pm 1.700$ \\
\hline TG (mg/dl) & $62.0^{\mathrm{a}} \pm 0.966$ & $61.8^{\mathrm{a}} \pm 1.492$ & $61.7^{\mathrm{a}} \pm 1.022$ \\
\hline HDL-ch (mg/dl) & $43.5^{\mathrm{a}} \pm 0.428$ & $44.2^{\mathrm{a}} \pm 0.307$ & $44.5^{\mathrm{a}} \pm 0.428$ \\
\hline LDL-Ch & $20^{\mathrm{a}} \pm 0.577$ & $19.2^{\mathrm{a}} \pm 0.401$ & $18.7^{\mathrm{a}} \pm 0.494$ \\
\hline Total protein $(\mathrm{g} / \mathrm{dl})$ & $7.6^{\mathrm{a}} \pm 0.123$ & $7.6^{\mathrm{a}} \pm 0.143$ & $7.7^{\mathrm{a}} \pm 0.088$ \\
\hline Albumin (g/dl) & $3.9^{\mathrm{a}} \pm 0.095$ & $3.7^{\mathrm{a}} \pm 0.061$ & $3.8^{\mathrm{a}} \pm 0.067$ \\
\hline Globulin (g/dl) & $3.7^{\mathrm{a}} \pm 0.139$ & $3.8^{\mathrm{a}} \pm 0.201$ & $3.8^{\mathrm{a}} \pm 0.042$ \\
\hline $\mathrm{A} / \mathrm{G}$ ratio & $1.1^{\mathrm{a}} \pm 0.055$ & $0.993^{\mathrm{a}} \pm 0.075$ & $1.0^{\mathrm{a}} \pm 0.018$ \\
\hline Glucose $(\mathrm{mg} / \mathrm{dl})$ & $74.7^{\mathrm{a}} \pm 1.174$ & $74^{\mathrm{a}} \pm 0.730$ & $73.7^{\mathrm{a}} \pm 0.615$ \\
\hline AST (U/l) & $41.5^{\mathrm{a}} \pm 0.763$ & $41.3^{\mathrm{a}} \pm 0.714$ & $41.0^{\mathrm{a}} \pm 0.967$ \\
\hline ALT (U/l) & $20.7^{\mathrm{a}} \pm 0.494$ & $20.2^{\mathrm{a}} \pm 0.529$ & $20.0^{\mathrm{a}} \pm 0.304$ \\
\hline Creatinine $(\mathrm{mg} / \mathrm{dl})$ & $0.57^{\mathrm{a}} \pm 0.012$ & $0.580^{\mathrm{a}} \pm 0.018$ & $0.574^{\mathrm{a}} \pm 0.017$ \\
\hline Urea $(\mathrm{mg} / \mathrm{dl})$ & $25.8^{\mathrm{a}} \pm 0.489$ & $25.6^{\mathrm{a}} \pm 0.803$ & $25.4^{\mathrm{a}} \pm 0.775$ \\
\hline
\end{tabular}

In each column same letter means non-significant difference while a different letter means significant difference at 0.05 probability. The data are expressed as mean values \pm standard error.

\subsection{Chemical composition of raw materials (WF, SP) and pasta.}

The chemical composition of raw materials (SP and WF) and different pasta samples are presented in Table 2. As illustrated in Table 2, SP showed the highest content of protein $(61.50 \%)$, fat $(6.02 \%)$, ash (13.65\%) and fiber (4.02\%), and lowest content of carbohydrates 
(14.81\%), while WF appeared the highest content of carbohydrates $(86.40 \%)$ following the reduction of other determined parameters (protein, fat, ash and fiber). These results of the chemical composition of SP are in agreement with the previous results proved by Sahin[29]. The results of WF chemical composition were in agreement with previous results reported by Hussein et al. [30-32]. SP content of all minerals determined (Ca, Fe, $\mathrm{Zn}, \mathrm{Mg}, \mathrm{Na}$, and $\mathrm{K}$ ) in the present study was high compared with WF (Table 2). It was reported previously that SP is a valued source of several minerals such as potassium, calcium, magnesium, selenium, iron, zinc, and many others $[4,33]$. Amino acid profile (Table 2) of SP revealed the presence of high content of essential and nonessential amino acids. Leucine and alanine were the major essential amino and nonessential amino acid present in SP, respectively, while histidine and cysteine was the lowest essential amino and nonessential amino acid present in SP, respectively. Based on the FAO and WHO composition of ideal protein, SP is one of the highest protein content according to a high presence of essential amino acids [4]. Enrichment of WF by SP by different concentrations $(0,2.5,5, \& 10 \%)$ enhances the chemical composition of the prepared pasta. The protein content of all the prepared pasta samples increased following the increment of SP addition. So the prepared pasta in the present research can be used as functional food rich in protein and minerals, especially calcium and iron. It was proved previously that SP's addition in the range of 1.5 to 6 increases the protein and mineral content of food products $[34,35]$.
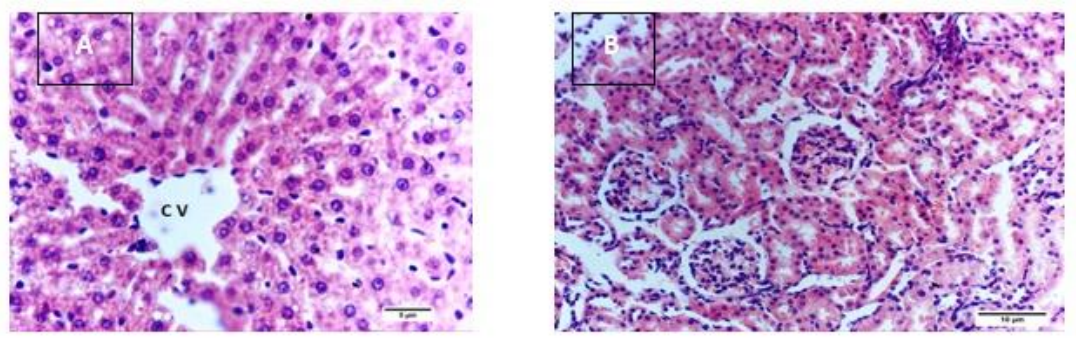

Figure 1. Photomicrograph of Liver and kidney tissue of different experimental groups.

Figure 1A: Photomicrograph of hepatic tissue. Showing the normal architecture of hepatic cords (H\&E,X 200). Figure 1 B: Photomicrograph of kidney sections of rats stained with H\&E (X 100). The normal architecture of renal corpuscles (glomeruli and capsules) and tubules are within the normal limit (H\&E, X 100).

\subsection{Rheological properties of blends from wheat flour with Spirulina.}

All rheological parameters (water absorption, arrival time, dough development time, mixing tolerance index and dough weakening) increased with the increment of SP concentration, as illustrated in Table 3. Elevation in all rheological parameters observed in the present research may be attributed to high protein content in SP (61.5\%), which led to the enlarged water absorption capacity of different pasta samples and all the studied rheological parameters. The present results are in agreement with the results of Barkallah et al. [36]. Increased dough development time may be due to the presence of an increased amount of fiber and protein, which may interfere with the quick development of gluten and hydration of endosperm [37]. The addition of SP powder also increased the arrival time and development time and decreased stability time of the dough compared with control. Dough stability is the only rheology parameter reduced (11 $\mathrm{min}$ in control to $5.5 \mathrm{~min}$ in pasta $10 \% \mathrm{SP}$ ) following the increment of SP level as observed in Table 3, mixing tolerance index and dough weakening increased with the enrichment of SP, which may occur due to a reduction in gluten content by the addition of SP following the elevation of fiber content. It was reported that fibers affect dough mixing properties through interaction with gluten [38]. 


\subsection{Color, cooking quality, and texture of pasta.}

The color of pasta is a very important quality attribute for consumer's acceptability [39]. The color of pasta depends on the materials used in the preparation and method used for processing [40]. According to color measurements adding SP in pasta offered an attractive green tendency (Table 4 and Figure 2). The darkness $\left(\mathrm{L}^{*}\right)$ of pasta is increased following SP addition due to the green color of SP compared with control pasta ( $0 \%$ SP), which appears the lowest $\mathrm{b}^{*}$ value. Cooking led to a reduction in the darkness of the color and increased the samples' brightness, as illustrated in Table 4 and Figure 2. Reduction in pasta samples' darkness due to cooking may be attributed to SP pigments' diffusion into cooking water [41].

In the present study, weight increase, cooking loss, and volume increase were determined to measure pasta cooking quality (Table 5). All the studied parameters increased significantly with the addition level of SP. The increment in cooking quality parameters may be due to a high protein and fiber level in SP, which interacts with gluten in WF. Gluten content in WF is responsible for weight gain in pasta. Gluten is responsible for making the internal network capable of retaining pasta components [41-43]. The increase in pasta containing SP may be attributed to the non-formation of the protein network in the presence of alginate, causing high starch hydration, leading to increased weight [41]. The increment in a loss in the present study is less than $12 \%$, this meaning that the addition of SP produces good-quality pasta [42]. During pasta cooking, part of soluble starch and non-starch polysaccharides leached into the water, which thickens the cooking water [43]. The present results are in agreement with the results of Özyurt et al. [44].

Table 2. Chemical composition of WF, SP and different pasta samples (dry weight basis).

\begin{tabular}{|c|c|c|c|c|c|c|c|}
\hline \multirow[t]{2}{*}{ Parameters } & \multirow{2}{*}{$\begin{array}{l}\text { Spirulina } \\
\text { (SP) }\end{array}$} & \multirow{2}{*}{$\begin{array}{l}\text { Wheat flour } \\
\text { (WF) }\end{array}$} & \multicolumn{5}{|c|}{ Pasta samples containing different concentration of Spirulina } \\
\hline & & & $\begin{array}{l}\text { Control } \\
(0 \% \text { SP) } \\
\end{array}$ & $2.5 \% \mathrm{SP}$ & $5.0 \% \mathrm{SP}$ & $7.5 \% \mathrm{SP}$ & $10 \% \mathrm{SP}$ \\
\hline Protein $(\mathrm{g} / 100 \mathrm{~g})$ & $61.50 \pm 1.16$ & $10.90 \pm 0.15$ & $11.00 \pm 0.07$ & $12.52 \pm 0.09$ & $14.02 \pm 0.05$ & $15.52 \pm 0.11$ & $17.03 \pm 0.13$ \\
\hline Fat $(\mathrm{g} / 100 \mathrm{~g})$ & $6.02 \pm 0.10$ & $1.22 \pm 0.06$ & $1.28 \pm 0.001$ & $1.40 \pm 0.003$ & $1.55 \pm 0.002$ & $1.70 \pm 0.005$ & $1.80 \pm 0.006$ \\
\hline Fiber $(\mathrm{g} / 100 \mathrm{~g})$ & $4.02 \pm 0.0 .11$ & $0.45 \pm 0.01$ & $0.52 \pm 0.0$ & $0.65 \pm 0.001$ & $0.73 \pm 0.003$ & $0.81 \pm 0.002$ & $0.92 \pm 0.001$ \\
\hline Carbohydrate $(\mathrm{g} / 100 \mathrm{~g})$ & $14.81 \pm 0.29$ & $86.40 \pm 0.65$ & $86.38 \pm 0.72$ & $84.38 \pm 0.65$ & $82.32 \pm 0.72$ & $80.26 \pm 0.66$ & $78.20 \pm 0.59$ \\
\hline $\operatorname{Ash}(g / 100 \mathrm{~g})$ & $13.65 \pm 0.17$ & $0.75 \pm 0.03$ & $0.82 \pm 0.01$ & $1.05 \pm 0.03$ & $1.38 \pm 0.05$ & $1.71 \pm 0.03$ & $2.05 \pm 0.02$ \\
\hline \multicolumn{8}{|c|}{ Minerals } \\
\hline $\mathrm{Ca}(\mathrm{mg} / 100 \mathrm{~g})$ & 165.1 & 50.89 & 49.15 & 55.22 & 60.16 & 65.10 & 70.15 \\
\hline $\mathrm{Fe}(\mathrm{mg} / 100 \mathrm{~g})$ & 56.6 & 2.35 & 2.92 & 3.62 & 4.15 & 5.05 & 7.17 \\
\hline $\mathrm{Zn}(\mathrm{mg} / 100 \mathrm{~g})$ & 4.5 & 3.36 & 3.22 & 3.28 & 3.35 & 3.40 & 3.65 \\
\hline $\mathrm{Mg}(\mathrm{mg} / 100 \mathrm{~g})$ & 12.9 & 368.33 & 366.22 & 350.15 & 340.22 & 335.35 & 330.19 \\
\hline $\mathrm{K}(\mathrm{mg} / 100 \mathrm{~g})$ & 133.11 & 695.33 & 692.11 & 675.10 & 660.14 & 655.09 & 645.06 \\
\hline $\mathrm{Na}(\mathrm{mg} / 100 \mathrm{~g})$ & 762 & 630.18 & 625.11 & 630.19 & 640.25 & 650.33 & 665.19 \\
\hline \multicolumn{8}{|c|}{ Amino Acids (g/100 g protein) } \\
\hline \multicolumn{8}{|c|}{ Essential amino acids } \\
\hline Isoleucine & 4.02 & 2.68 & 2.83 & 2.95 & 3.10 & 3.25 & 4.02 \\
\hline Leucine & 7.67 & 5.44 & 5.61 & 5.78 & 5.92 & 6.12 & 7.67 \\
\hline Lysine & 5.36 & 2.06 & 2.03 & 2.01 & 1.96 & 1.93 & 5.36 \\
\hline Methionine & 3.18 & 2.05 & 2.22 & 2.40 & 2.55 & 2.72 & 3.18 \\
\hline Phenylalanine & 5.47 & 4.91 & 4.87 & 4.83 & 4.79 & 4.75 & 5.47 \\
\hline Threonine & 5.22 & 2.59 & 2.63 & 2.69 & 2.72 & 2.75 & 5.22 \\
\hline Valine & 5.63 & 4.19 & 4.29 & 4.38 & 4.45 & 4.50 & 5.63 \\
\hline Histidine & 1.34 & 2.32 & 2.30 & 2.27 & 2.22 & 2.20 & 1.34 \\
\hline \multicolumn{8}{|c|}{ Nonessential amino acids } \\
\hline Tyrosine & 5.97 & 3.57 & 3.80 & 3.96 & 4.10 & 4.50 & 5.97 \\
\hline Arginine & 6.75 & 4.10 & 4.27 & 4.60 & 4.90 & 5.02 & 6.75 \\
\hline Alanine & 8.76 & 3.03 & 3.25 & 3.55 & 3.72 & 3.95 & 8.76 \\
\hline Aspartic & 7.99 & 4.46 & 4.62 & 4.80 & 4.97 & 5.14 & 7.99 \\
\hline Cysteine & 1.72 & 3.12 & 3.08 & 3.05 & 3.02 & 3.00 & 1.72 \\
\hline Glutamic & 10.49 & 33.72 & 33.65 & 33.06 & 32.90 & 32.70 & 10.49 \\
\hline Glycine & 5.04 & 3.57 & 3.65 & 3.72 & 3.88 & 3.95 & 5.04 \\
\hline Proline & 3.98 & 9.81 & 9.60 & 9.25 & 9.07 & 8.82 & 3.98 \\
\hline Serine & 4.09 & 3.92 & 3.90 & 3.95 & 4.02 & 4.08 & 4.09 \\
\hline
\end{tabular}

Table 3. Effect of mixing Spirulina powder with Wheat flour on rheological properties of farinograph. 


\begin{tabular}{l|c|c|c|c|c|c}
\hline Samples & $\begin{array}{c}\text { Water } \\
\text { absorption (\%) }\end{array}$ & $\begin{array}{c}\text { Arrival } \\
\text { time (min) }\end{array}$ & $\begin{array}{c}\text { Dough } \\
\text { development } \\
\text { time (min) }\end{array}$ & $\begin{array}{c}\text { Dough } \\
\text { stability } \\
(\mathbf{m i n})\end{array}$ & $\begin{array}{c}\text { Mixing } \\
\text { tolerance } \\
\text { index (BU) }\end{array}$ & $\begin{array}{c}\text { Dough } \\
\text { weakening } \\
\text { (BU) }\end{array}$ \\
\hline Control (0 \% SP) & 60.5 & 1.05 & 1.50 & 11.00 & 30 & 100 \\
\hline Pasta 2.5\% SP & 62.8 & 1.30 & 2.00 & 9.50 & 35 & 110 \\
\hline Pasta 5\% SP & 65.5 & 1.75 & 2.50 & 8.00 & 40 & 115 \\
\hline Pasta 7.5\% SP & 68.0 & 2.05 & 3.00 & 6.50 & 50 & 120 \\
\hline Pasta 10\% SP & 71.5 & 2.50 & 3.50 & 5.50 & 55 & 130
\end{tabular}

Table 4. Effect of mixing Spirulina powder with wheat flour on a color parameter of pasta.

\begin{tabular}{l|c|c|c|c|c|c}
\multirow{2}{*}{ Samples } & \multicolumn{2}{|c}{$\mathrm{L}^{*}$} & \multicolumn{2}{c}{$\mathrm{a}^{*}$} & \multicolumn{2}{c}{$\mathrm{b}^{*}$} \\
\cline { 2 - 7 } & Raw & Cooked & Raw & Cooked & Raw & Cooked \\
\hline Control (0 \% SP) & $75.15^{\mathrm{a}} \pm 0.33$ & $71.22^{\mathrm{a}} \pm 0.52$ & $1.59^{\mathrm{e}} \pm 0.03$ & $3.25^{\mathrm{e}} \pm 0.06$ & $19.15^{\mathrm{e}} \pm 0.10$ & $15.19^{\mathrm{a}} \pm 0.15$ \\
\hline Pasta 2.5\% SP & $59.18^{\mathrm{b}} \pm 0.36$ & $66.19^{\mathrm{b}} \pm 0.41$ & $5.84^{\mathrm{d}} \pm 0.09$ & $4.19^{\mathrm{d}} \pm 0.13$ & $23.15^{\mathrm{d}} \pm 0.15$ & $27.35^{\mathrm{b}} \pm 0.19$ \\
\hline Pasta 5\% SP & $51.65^{\mathrm{c}} \pm 0.28$ & $58.71^{\mathrm{c}} \pm 0.38$ & $7.11^{\mathrm{c}} \pm 0.035$ & $5.22^{\mathrm{c}} \pm 0.19$ & $26.15^{\mathrm{c}} \pm 0.23$ & $30.22^{\mathrm{c}} \pm 0.33$ \\
\hline Pasta 7.5\% SP & $46.58^{\mathrm{d}} \pm 0.45$ & $53.19^{\mathrm{d}} \pm 0.29$ & $8.12^{\mathrm{b}} \pm 0.02$ & $6.17^{\mathrm{b}} \pm 0.22$ & $28.57^{\mathrm{b}} \pm 1.02$ & $34.14^{\mathrm{d} \pm 0.56}$ \\
\hline Pasta 10\% SP & $39.18^{\mathrm{e}} \pm 0.82$ & $45.60^{\mathrm{e}} \pm 0.37$ & $9.13^{\mathrm{a}} \pm 0.09$ & $7.15^{\mathrm{a}} \pm 0.15$ & $31.17^{\mathrm{a}} \pm 1.11$ & $37.10^{\mathrm{e}} \pm 0.62$ \\
\hline LSD at 0.05 & 6.15 & 5.03 & 1.06 & 0.92 & 1.79 & 2.87
\end{tabular}

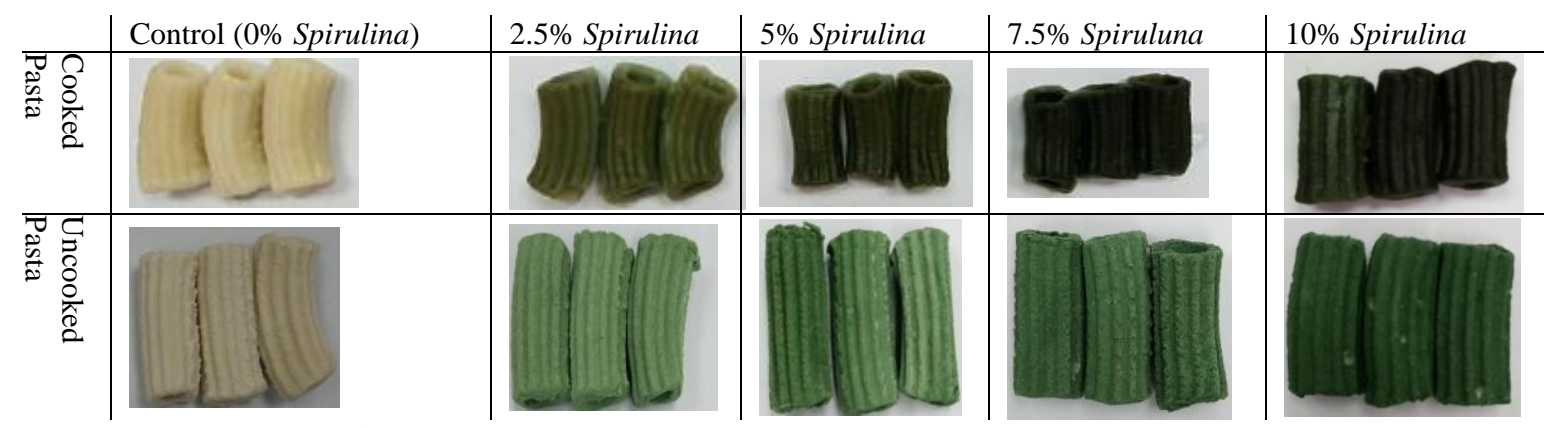

Figure 2. Different pasta samples containing Spirulina powder.

Table 5. Effect of mixing Spirulina powder with wheat flour on pasta cooking quality. p.

\begin{tabular}{l|c|c|c} 
Samples & Weight increase (\%) & Volume increase (\%) & Cooking loss (\%) \\
\hline Control (0\% SP) & $215^{\mathrm{e}} \pm 2.12$ & $160^{\mathrm{e}} \pm 3.25$ & $3.30^{\mathrm{e}} \pm 0.110$ \\
\hline Pasta 2.5\% SP & $235^{\mathrm{d}} \pm 3.22$ & $173^{\mathrm{d}} \pm 3.05$ & $4.10^{\mathrm{d}} \pm 0.112$ \\
\hline Pasta 5\% SP & $243^{\mathrm{c}} \pm 4.15$ & $192^{\mathrm{c}} \pm 4.15$ & $4.70^{\mathrm{c}} \pm 0.165$ \\
\hline Pasta 7.5\% SP & $260^{\mathrm{b}} \pm 5.20$ & $209^{\mathrm{b}} \pm 3.10$ & $5.01^{\mathrm{b}} \pm 0.121$ \\
\hline Pasta 10\% SP & $280^{\mathrm{a}} \pm 3.12$ & $220^{\mathrm{a}} \pm 2.85$ & $5.25^{\mathrm{a}} \pm 0.130$ \\
\hline LSD at 0.05 & 9.954 & 10.921 & 0.268
\end{tabular}

Values in the same column followed by the same letter are not significant $(P<0.05)$.

Texture parameters of pasta prepared from WF and WF supplemented with $\mathrm{Sp}$ at different levels $(2.5,5.0,7.5$, and 10\%) are given in Table (6). Texture parameters, mainly, Hardness $(\mathrm{N})$, Deformation at hardness $(\mathrm{mm})$, Deformation at hardness (\%), Hardness work $(\mathrm{mJ})$, load at target $(\mathrm{N})$, Peak Stress $\left(\mathrm{N} / \mathrm{m}^{2}\right)$, strain at peak load, Fracturability $(\mathrm{N})$ and Fracturability with $1 \%$ of load sensitivity $(\mathrm{N})$. These texture parameters of the pasta and pasta enriched with SP were estimated as the ultimate force given by the sample during cutting in a texture-testing machine (Instron). Results demonstrated that the Hardness (N) for all pasta samples ranged between 72.07 to $44.55 \mathrm{~N}$. On the other hand, the higher hardness for pasta without SP related to low moisture and increase hardness; on the other side, increased work done. The hardness of pasta is a sense to consumers and may be correlated with the dilation and cell structure of the product, independent of the moisture content in the product, these results are in agreement with De Marco et al., Raja et al., and Jaworska et al.[45-47]. The observed results of texture analysis, it could be decided that enrichment with SP at different levels $(0,2.5,5.0,7.5$ and 10\%) was able to decrease Hardness $(\mathrm{N})$, Deformation at hardness $(\mathrm{mm})$, Deformation at hardness $(\%)$, Hardness work $(\mathrm{mJ})$ and Fracturability with $1 \%$ of load sensitivity $(\mathrm{N})$ of pasta. On the other hand, the hardness value decreased when SP level in the 
Pasta formulations was increased. On the contrary, supplementation WF with SP increased the hardness value of pasta.

\subsection{Sensory properties.}

Results of sensorial evaluation revealed that all organoleptic parameters (color, flavor, mouthfeel, and overall acceptability) of Spirulina-enriched pasta (7.5 and 10\%) were reduced significantly compared with the control (0\% SP) sample (Table 7), while elasticity was the only parameters change non-significantly. From the presented results in Table 7, the sensory characteristics were decreased with increasing the level addition of SP. Color as one of the organoleptic parameters was reduced significantly in accordance with SP addition level. This result in the case of the color parameter may be attributed to the dark color $\left(\mathrm{L}^{*}\right)$ due to SP pigments as observed in the color measurements (Table 4). Pasta may be enriched with SP at levels 2.5 or $5.0 \%$ without any reverse effect on the product's sensory acceptance. . The present outcomes are compatible with the results of Zen et al. [41].

Table 6. Effect of mixing Spirulina powder with wheat flour on Texture profile analysis of pasta.

\begin{tabular}{|c|c|c|c|c|c|c|c|c|c|c|}
\hline \multirow[t]{2}{*}{ Parameters } & \multicolumn{2}{|c|}{ Control (0\% SP) } & \multicolumn{2}{|c|}{$2.5 \% \mathrm{SP}$} & \multicolumn{2}{|c|}{$5 \% \mathrm{SP}$} & \multicolumn{2}{|c|}{$7.5 \% \mathrm{SP}$} & \multicolumn{2}{|c|}{$10 \% \mathrm{SP}$} \\
\hline & Raw & Cooked & Raw & Cooked & Raw & Cooked & Raw & Cooked & Raw & Cooked \\
\hline Hardness (N) & 72.07 & 7.02 & 53.13 & 7.05 & 53.90 & 6.93 & 53.70 & 5.49 & 44.55 & 6.88 \\
\hline Deformation at hardness (mm) & 0.26 & 8.56 & 0.23 & 8.79 & 6.22 & 10.78 & 5.54 & 10.57 & 8.30 & 11.12 \\
\hline$\%$ Deformation at hardness (\%) & 0.90 & 85.60 & 0.80 & 87.90 & 20.70 & 107.80 & 18.50 & 105.70 & 27.70 & 111.20 \\
\hline Hardness work (mJ) & 0.40 & 22.50 & 13.20 & 22.90 & 39.10 & 33.80 & 50.90 & 25.20 & 63.70 & 39.60 \\
\hline Load at Target $(\mathrm{N})$ & 72.07 & 7.02 & 53.13 & 7.05 & 41.48 & 6.93 & 53.70 & 5.49 & 44.55 & 6.88 \\
\hline Peak Stress $\left(\mathrm{N} / \mathrm{m}^{2}\right)$ & 36704 & 3576 & 27060 & 3591 & 21127 & 3531 & 27350 & 2797 & 22690 & 3506 \\
\hline Strain at Peak Load & 0.01 & 0.86 & 0.01 & 0.88 & 0.21 & 1.08 & 0.18 & 1.06 & 0.28 & 1.11 \\
\hline Fracturability (N) & 72.07 & 0.37 & 53.13 & 0.31 & 29.92 & 0.21 & 32.91 & 0.42 & 36.03 & 0.58 \\
\hline Fracture Load Drop Off $(\mathrm{N})$ & 64.02 & 0.15 & 45.83 & 0.08 & 28.53 & 0.17 & 28.93 & 0.12 & 27.30 & 0.13 \\
\hline $1^{\text {st }}$ Fracture Work Done $(\mathrm{mJ})$ & 11.90 & 0.02 & 7.40 & 0.03 & 3.30 & 0.02 & 5.00 & 0.10 & 7.90 & 0.13 \\
\hline $\mathbf{1}^{\text {st }}$ Fracture Deformation $(\mathrm{mm})$ & 0.26 & 0.20 & 0.23 & 0.30 & 0.17 & 0.20 & 0.23 & 1.00 & 0.32 & 1.30 \\
\hline $\mathbf{1}^{\text {st }}$ Fracture \% Deformation (\%) & 0.90 & 7.02 & 0.80 & 7.05 & 0.60 & 12.93 & 0.80 & 12.01 & 1.10 & 11.54 \\
\hline
\end{tabular}

Table 7. Effect of mixing Spirulina powder with wheat flour on pasta's sensory properties.

\begin{tabular}{l|c|c|c|c|c|c} 
Samples & $\begin{array}{c}\text { Color } \\
(\mathbf{1 0})\end{array}$ & $\begin{array}{c}\text { Flavor } \\
(\mathbf{1 0})\end{array}$ & $\begin{array}{c}\text { Mouthfeel } \\
(\mathbf{1 0})\end{array}$ & $\begin{array}{c}\text { Elasticity } \\
(\mathbf{1 0})\end{array}$ & $\begin{array}{c}\text { OAA } \\
(\mathbf{1 0})\end{array}$ & $\begin{array}{c}\text { Total } \\
(\mathbf{5 0})\end{array}$ \\
\hline Control (0\% SP) & $9.91^{\mathrm{a}} \pm 0.61$ & $9.81^{\mathrm{a}} \pm 0.33$ & $9.80^{\mathrm{a}} \pm 0.43$ & $9.75^{\mathrm{a}} \pm 0.55$ & $9.62^{\mathrm{a}} \pm 0.26$ & $48.59^{\mathrm{a}} \pm 1.19$ \\
\hline Pasta 2.5\% SP & $9.01^{\mathrm{b}} \pm 0.44$ & $9.33^{\mathrm{a}} \pm 0.45$ & $9.41^{\mathrm{a}} \pm 0.52$ & $9.50^{\mathrm{a}} \pm 0.41$ & $9.11^{\mathrm{a}} \pm 0.35$ & $46.36^{\mathrm{a}} \pm 1.28$ \\
\hline Pasta 5\% SP & $8.12^{\mathrm{c}} \pm 0.52$ & $8.44^{\mathrm{b}} \pm 0.37$ & $8.80^{\mathrm{a}} \pm 0.55$ & $9.21^{\mathrm{a}} \pm 0.37$ & $8.80^{\mathrm{a}} \pm 0.42$ & $43.37^{\mathrm{b}} \pm 1.51$ \\
\hline Pasta 7.5\% SP & $7.35^{\mathrm{c}} \pm 0.82$ & $8.15^{\mathrm{b}} \pm 0.56$ & $7.85^{\mathrm{b}} \pm 0.61$ & $9.15^{\mathrm{a}} \pm 0.49$ & $8.10^{\mathrm{b}} \pm 0.29$ & $40.06^{\mathrm{b}} \pm 1.32$ \\
\hline Pasta 10\% SP & $6.44^{\mathrm{d}} \pm 0.70$ & $7.35^{\mathrm{c}} \pm 0.41$ & $6.82^{\mathrm{c}} \pm 0.56$ & $9.01^{\mathrm{a}} \pm 0.61$ & $7.35^{\mathrm{c}} \pm 0.33$ & $36.97^{\mathrm{c} \pm 1.12}$ \\
\hline LSD at 0.05 & 0.8120 & 0.8330 & 0.9320 & NS & 0.8016 & 2.181
\end{tabular}

Values in the same column followed by the same letter are not significant $(P<0.05)$.

\subsection{Total phenolic content (TPC) and antioxidant capacity.}

Due to their antioxidant properties and radical scavenging activity, much attention was gained to phenolic compounds [48, 49]. Therefore, the phenolic content of control and fortified samples was determined using the Folin-Ciocalteu method, and the obtained results are given in Table 8.The data showed a remarkable increase in phenolic content in supplemented pasta was recorded with increasing SP's added level and reach a maximum value at a level of 10\%, which had $3.12 \mathrm{mg} / \mathrm{g}$. The phenolic content of SP extract was $13.65 \mathrm{mg} / \mathrm{g}$ in the range of previous studies carried out by Finamore et al. [50]. The variations in obtained results between us and another investigation may be due to algae species, environmental conditions, and origin and characteristics of used samples. However, most of the studies referred to that SP are a promising source for phenolic compounds, which could be used in the food industry and pharmaceutical products. 
Our data in Table 8 exhibited a significant increase in pasta's phenolic content $\mathrm{p}$ enriched with Spirulina which had about 4-fold in the level of 10\% compared to control only and approximately 2 -fold in first level $2.5 \%$ in dried pasta. These data, according to De Marco et al. and Fradinho et al. [45, 51] found an increase in total phenol of cooked pasta enriched with Spirulina's biomass. In the cereal grain, the high antioxidant activity may be due to phenolic content [52]. In the enriched pasta samples, the increase in antioxidant activity may be due to the rich content of antioxidants in SP such as $\gamma$-Linolenic, carotenoids, and vitamins [53].

The antioxidant activity of pasta samples was analyzed by DPPH radical scavenging activity and reducing power property and is reported in Table 8. Incorporating Spirulina in pasta formulation has a significant increase in the antioxidant capacity compared to control treatment. The two methods used in the current study DPPH and reducing power exhibited high antioxidant capacity at a level of $10 \%$ with concentrations of 51.8 and $40.6 \mu \mathrm{mol} / \mathrm{g}$ sample in dried pasta. Our data showed no significant difference between levels of 2.5 and $5 \%$ as well as $7.5 \%$ and $10 \%$ when the determination was carried out by reducing power method (Table 8). The two assays showed that level $10 \%$ had the highest antioxidant activity, which correlated with the highest total phenolic content 3.12 and $2.95 \mathrm{mg} / \mathrm{g}$ in uncooked and cooked pasta, respectively. The fresh prepared, cooked pasta exhibited a remarkable decrease in antioxidant activity than uncooked treatments, which correlated to thermal treatment during boiling and loss of biologically active compounds in this water. However, the supplemented treatments still had a significant increase in antioxidant activity after cooking compared to control. The obtained results agreed with Fradino et al. [51]; who mentioned that fortification of pasta with Spirulina elevates it is antioxidant compared to the untreated sample.

Table 8. Effect of cooking on total phenolic content and antioxidant capacity using DPPH and reducing power in pasta enriched with Spirulina.

\begin{tabular}{l|c|c|c} 
Sample & TPC $(\mathbf{m g} / \mathbf{g})$ & DPPH $(\boldsymbol{\mu m o l} / \mathbf{g})$ & Reducing power $(\boldsymbol{\mu m o l} / \mathbf{g})$ \\
\hline Spirulina $(\mathbf{S P})$ & $13.65 \pm 0.12^{\mathrm{a}}$ & $80.2 \pm 0.09^{\mathrm{a}}$ & $64.8 \pm 0.15^{\mathrm{a}}$ \\
\hline Control 0\% SP & & Before cooking & $11.3 \pm 0.38$ \\
\hline Pasta 2.5\% SP & $0.85 \pm 0.19$ & $12.9 \pm 0.13$ & $29.5 \pm 0.22^{\mathrm{b}}$ \\
\hline Pasta 5\% SP & $2.94 \pm 0.25^{\mathrm{b}}$ & $31.4 \pm 0.21$ & $31.4 \pm 0.17$ \\
\hline Pasta 7\% SP & $2.45 \pm 0.34^{\mathrm{c}}$ & $42.9 \pm 0.19^{\mathrm{b}}$ & $38.2 \pm 0.45$ \\
\hline Pasta10\% SP & $3.12 \pm 0.42$ & $48.7 \pm 0.18$ & $40.6 \pm 0.14$ \\
\hline & & $51.8 \pm 0.20$ & $9.45 \pm 0.16$ \\
\hline Control 0\% SP & $0.72 \pm 0.21$ & After cooking & $18.27 \pm 0.45$ \\
\hline Pasta 2.5\% SP & $1.56 \pm 0.15$ & $10.29 \pm 0.31$ & $26.81 \pm 0.18$ \\
\hline Pasta 5\% SP & $1.95 \pm 0.19^{\mathrm{b}}$ & $28.35 \pm 0.25$ & $29.65 \pm 0.39^{\mathrm{b}}$ \\
\hline Pasta 7\% SP & $2.13 \pm 0.24^{\mathrm{c}}$ & $39.47 \pm 0.16$ & $31.58 \pm 0.42$ \\
\hline
\end{tabular}

\subsection{Volatile compounds of pasta enriched with Spirulina.}

The selected sample of pasta enriched with Spirulina (2.5\% level) which had maximum sensory evaluation scores compared to control treatment, were subjected to analysis of volatile compounds using the headspace method with SPME revealed a total of twenty-five volatile compounds (Table 9). The identified volatile constituents can be classified as the following; alcohols (7), aldehydes (6), hydrocarbons (4), ketone (4), terpene (2), ester (1), and furan (1). The most predominant identified volatile compounds were hexanal and 2-pentylfuran, which represent $(35.16 \%)$ and $(15.28 \%)$ in fresh control, respectively (Table 9). These data are following Giannetti et al. [54]. The concentration of 2-pentylfuran and hexanal play a 
domestic role in the acceptability of pasta due to their low odor threshold values [55,56 ]. The low concentrations of the volatiles above in fortified pasta samples compared to the control treatment may explain the low sensory evaluation scores. Millard reaction and oxidation of oleic and linoleic fatty acids lead to the formulation of alcohols (2,3-butanediol) and aldehydes (decanal, nonanal, heptanal and hexanal), respectively, which reduced when Spirulina incorporated in pasta. The only ester detected was ethyl hexanoate with a concentration of $0.29 \%$ in the control sample. Some volatile compounds were strongly related to the durum wheat cultivar [55 ]. The explanation of esters' disappearance in enriched samples may be due to the significantly high concentration of aldehydes in fortified pasta [57 ]. On the other hand, volatile compounds such as alcohols and aldehydes or furan are lipid oxidation products or formed via Millard reaction during pasta preparation.

The concentration of fatty acids, linoleic and linolenic, correlated with the presence of alcohols (1-hexanol and 1-otcen-3-ol) and aldehydes (benzaldehyde and hexanal) [58, 59]. Adamiec et al. [60 ] mentioned that benzaldehyde is a degradation product of phenylalanine. Therefore, the increase of benzaldehyde by $6.12 \%$ in a fortified sample compared to $1.19 \%$ in the control sample may be due to streckerthermal degradation. Additionally, Millard reaction products such as 2-octanone and aldehydes from Strecker degradation like benzaldehyde and octanal were significantly higher in fortified pasta than control pasta (Table 9). The Millard reaction products are known as potent antioxidant compounds [61 ]. This could explain the high antioxidant activity of fortified pasta compared to the control sample.

Table 9. Aroma volatile compounds in cooked pasta from wheat durum and supplemented with 2.5\% Spirulina.

\begin{tabular}{l|l|l|l|l} 
Volatile compounds & KI $^{\mathbf{a}}$ & Control & Pasta 2.5 \% SP & Chemical group \\
\hline 3-Methyl-1-butanol & 735 & $0.23^{\mathbf{b}}$ & 2.13 & Alcohols \\
\hline 2-Methyl-1-butanol & 738 & 0.35 & 0.09 & Alcohols \\
\hline 1-Pentanol & 782 & 3.59 & 6.94 & Alcohols \\
\hline 2,3-Butandiol & 841 & 1.49 & 1.26 & Alcohols \\
\hline 1-Hexanol & 887 & 9.4 & 3.18 & Alcohols \\
\hline 1-Heptanol & 982 & 0.2 & 3.15 & Alcohols \\
\hline 1-Octen-3-ol & 987 & 6.35 & 2.46 & Alcohols \\
\hline Toluene & 764 & 0.18 & 2.59 & Hydrocarbons \\
\hline Ethylbenzene & 869 & 1.93 & 1.82 & Hydrocarbons \\
\hline Undecane & 1115 & $\mathrm{ND}$ & 4.26 & Hydrocarbons \\
\hline Tridecane & 1312 & 0.11 & 2.19 & Hydrocarbons \\
\hline Hexanal & 807 & 35.16 & 25.17 & Aldehyde \\
\hline Heptanal & 916 & 4.54 & 2.15 & Aldehyde \\
\hline Octanal & 1008 & 1.46 & 3.25 & Aldehyde \\
\hline Nonanal & 1120 & 7.51 & 4.16 & Aldehyde \\
\hline Decanal & 1213 & 3.49 & 2.17 & Aldehyde \\
\hline Benzaldehyde & 968 & 1.19 & 6.12 & Aldehyde \\
\hline 2-Heptanone & 903 & 3.43 & 5.07 & Ketone \\
\hline 6-Methyl-2-heptanone & 967 & 1.34 & 3.19 & Ketone \\
\hline 2-Octanone & 1005 & 0.28 & 2.14 & Ketone \\
\hline 2-Nonanone & 1112 & 0.26 & 0.87 & Ketone \\
\hline Alpha-pinene & 941 & n.d & 0.34 & Terpene \\
\hline Limonene & 1034 & 1.25 & 0.31 & Terpene \\
\hline Ethyl hexanoate & 1009 & 0.29 & $\mathrm{ND}$ & Ester \\
\hline 2-Pentylfuran & 994 & 15.28 & 13.45 & Furan \\
\hline index; balues are expressed & relative area percentage; ND: & not detected & \\
\hline & & & &
\end{tabular}

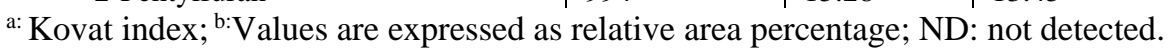

\section{Conclusions}

Spirulina is completely safe and could be used in the preparation of functional foods. Spirulina-enriched pasta is a rich source of protein and antioxidants. The enrichment of pasta caused a reduction in sensory scores with an increase in the addition level. This reduction may be due to the low concentration of 2-pentylfuran and hexanal flavor compounds. 


\section{Funding}

This research received no external funding.

\section{Acknowledgments}

This research has no acknowledgment.

\section{Conflicts of Interest}

The authors declare no conflict of interest.

\section{References}

1. Costa, J.A.V.; Freitas, B.C.B.; Rosa, G.M.; Moraes, L.; Morais, M.G.; Mitchell, B.G. Operational and economic aspects of Spirulina-based biorefinery. Bioresource Technology 2019, 292, https://doi.org/10.1016/j.biortech.2019.121946.

2. Lupatini, A.L.; Colla, L.M.; Canan, C.; Colla, E. Potential application of microalga Spirulina platensis as a protein source. Journal of the Science of Food and Agriculture 2017, 97, 724-732, https://doi.org/10.1002/jsfa.7987.

3. Satpathy, L.; Dash, D.; Sahoo, P.; Anwar, T.; Parida, S. Quantitation of Total Protein Content in Some Common Edible Food Sources by Lowry Protein Assay. Letters in App. Nano. Biosci. 2020, 9, 1275-1283, https://doi.org/10.33263/LIANBS93.12751283.

4. Lafarga, T.; Fernández-Sevilla, J.M.; González-López, C.; Acién-Fernández, F.G. Spirulina for the food and functional food industries. Food Research International 2020, 137, https://doi.org/10.1016/j.foodres.2020.109356.

5. Ismaiel, M.M.S.; El-Ayouty, Y.M.; Piercey-Normore, M. Role of $\mathrm{pH}$ on antioxidants production by Spirulina (Arthrospira) platensis. Brazilian Journal of Microbiology 2016, 47, 298-304, https://doi.org/10.1016/j.bjm.2016.01.003.

6. Rodriguez-Concepcion, M.; Avalos, J.; Bonet, M.L.; Boronat, A.; Gomez-Gomez, L.; Hornero-Mendez, D.; Limon, M.C.; Meléndez-Martínez, A.J.; Olmedilla-Alonso, B.; Palou, A.; Ribot, J.; Rodrigo, M.J.; Zacarias, L.; Zhu, C. A global perspective on carotenoids: Metabolism, biotechnology, and benefits for nutrition and health. Progress in Lipid Research 2018, 70, 62-93, https://doi.org/10.1016/j.plipres.2018.04.004.

7. Lafarga, T. Effect of microalgal biomass incorporation into foods: Nutritional and sensorial attributes of the end products. Algal Research 2019, 41, https://doi.org/10.1016/j.algal.2019.101566.

8. Niccolai, A.; Venturi, M.; Galli, V.; Pini, N.; Rodolfi, L.; Biondi, N.; D’Ottavio, M.; Batista, A.P.; Raymundo, A.; Granchi, L.; Tredici, M.R. Development of new microalgae-based sourdough "crostini": functional effects of Arthrospira platensis (spirulina) addition. Scientific Reports 2019, 9, https://doi.org/10.1038/s41598-019-55840-1.

9. Oliviero, T.; Fogliano, V. Food design strategies to increase vegetable intake: The case of vegetable enriched pasta. Trends in Food Science \& Technology 2016, 51, 58-64, https://doi.org/10.1016/j.tifs.2016.03.008.

10. Hansen, A.; Schieberle, P. Generation of aroma compounds during sourdough fermentation: applied and fundamental aspects. Trends in Food Science \& Technology 2005, 16, 85-94, https://doi.org/10.1016/j.tifs.2004.03.007.

11. Reid, L.M.; O’Donnell, C.P.; Downey, G. Recent technological advances for the determination of food authenticity. Trends in Food Science \& Technology 2006, 17, 344-353, https://doi.org/10.1016/j.tifs.2006.01.006.

12. Baiano, A.; Siciliano, P.; Taurino, A.M.; Presicce, D.S.; Gambacorta, G.; Lamacchia, C.; Pati, S.; La Notte, E. Electronic nose and GC-MS to investigate the volatile component of an Italian traditional pasta. Cereal foods world. 2007, 52, 138-143, https://europepmc.org/article/agr/ind43920391.

13. Gaggiotti, S.; Shkembi, B.; Sacchetti, G.; Compagnone, D. Study on volatile markers of pasta quality using GC-MS and a peptide based gas sensor array. LWT 2019, 114,https://doi.org/10.1016/j.lwt.2019.108364.

14. Goodman, G.; Goodman, S.; Gilman, A. Principles of Toxicology. In: The Pharmacological Basis of Therapeutics. Goodman, A.G.; Gilman, A. (Eds.). 12 $2^{\text {th }}$ Edn., Macmillan, New York, 2011.

15. Ekor, M.; Emerole, G.O.; Farombi, E.O. Phenolic extract of soybean (Glycine max) attenuates cisplatininduced nephrotoxicity in rats. Food and Chemical Toxicology 2010, 48, 1005-1012, https://doi.org/10.1016/j.fct.2009.12.027.

16. AACC. Approved Methods of Analysis. 10th Edn., American Association of Cereal Chemists, St. Paul, M.N. USA., ISBN-13: $9781891127120,2000$.

17. Chapman, D.; Pratt, F. Methods of Analysis for Soil, Plants and Water. Univ. of California, Div Agric Sci., Priced Publication, 1978. 
18. AOAC. Official Methods of Analysis of the Association of Official Analytical Chemists. 19th ed., Washington D.C., USA, 2012.

19. AACC. American Association of Cereal Chemists. Approved Methods of Analysis, 11th edn. AACC International, Saint Paul, 2010.

20. Singh, M.; Mohamed, A. Influence of gluten-soy protein blends on the quality of reduced carbohydrates cookies. LWT - Food Science and Technology 2007, 40, 353-360, https://doi.org/10.1016/j.lwt.2005.09.013.

21. Abu Bakar, M.F.; Mohamed, M.; Rahmat, A.; Fry, J. Phytochemicals and antioxidant activity of different parts of bambangan (Mangifera pajang) and tarap (Artocarpus odoratissimus). Food Chemistry 2009, 113, 479-483, https://doi.org/10.1016/j.foodchem.2008.07.081.

22. Gulluce, M.; Sahin, F.; Sokmen, M.; Ozer, H.; Daferera, D.; Sokmen, A.; Polissiou, M.; Adiguzel, A.; Ozkan, $\mathrm{H}$. Antimicrobial and antioxidant properties of the essential oils and methanol extract from Mentha longifolia L. ssp. longifolia. Food Chemistry 2007, 103, 1449-1456, https://doi.org/10.1016/j.foodchem.2006.10.061.

23. Braca, A.; De Tommasi, N.; Di Bari, L.; Pizza, C.; Politi, M.; Morelli, I. Antioxidant Principles from Bauhinia tarapotensis. Journal of Natural Products 2001, 64, 892-895,https://doi.org/10.1021/np0100845.

24. Oyaizu, M. Studies on products of browning reaction. Antioxidative activities of products of browning reaction prepared from glucosamine. Japa. J. Nutr.1986, 44, 307314,https://doi.org/10.5264/eiyogakuzashi.44.307.

25. Adams, R. Identification of essential oil components by gas chromatography/mass spectrometry. Allured Publishing Carol Steam Ilionois, USA. 2007

26. Paget, P.; Barnes, T. Evaluation of Drug Activities Pharmacometrics. eds. Laurrence, D.R.; Bacharach, A.R. Academic Press, London and New York, 1974; pp. 135-140,https://doi.org/10.1002/jps.2600540740.

27. Athané, A.; Demol, J.; Brosset-Vincent, S.; Aguenou, C.; Krisa, S.; Courtois, A.; Griffiths, H.; Cagnac, O. The safety evaluation of phycocyanin-enriched Galdieria sulphuraria extract using 90-day toxicity study in rats and in vitro genotoxicity studies. Toxicology Research and Application 2020, 4, 1-15, https://doi.org/10.1177/2397847320929991.

28. Gutiérrez-Salmeán, G.; Fabila-Castillo, L.; Chamorro-Cevallos, G. Nutritional And Toxicological Aspects Of Spirulina (Arthrospira). Nutricion hospitalaria 2015, 32, 34-40, https://doi.org/10.3305/nh.2015.32.1.9001.

29. Şahin, O.I. Functional and sensorial properties of cookies enriched with SPIRULINA and DUNALIELLA biomass. Journal of Food Science and Technology 2020, 57, 3639-3646, https://doi.org/10.1007/s13197020-04396-4.

30. Hussein, S.; Ali, S.; Al-Khalifa, A. Quality Assessment of Some Spring Bread Wheat Cultivars. Asian J. Crop Sci.2018, 10, 10-21,https://doi.org/10.3923/ajcs.2018.10.21.

31. Hussein, S.; Mahmoud, F.; Hegazy, A.; Kamil, M.; Mohammad, A.; Mehaya, M. Efficiency of Micro and Nano Encapsulated Orange Peel Essential Oils on Quality of Sponge Cake. J. Environ. Sci. Techn.2019,12, 26-37,https://doi.org/10.3923/jest.2019.26.37.

32. Hussein, A.; Ali, H.; Bareh, G.; Farouk, A.Influence of spent coffee ground as fiber source on chemical, rheological and sensory properties of sponge cake. Pak. J. Biolo. Sci.2019,22, 273282,https://doi.org/10.3923/pjbs.2019.273.282.

33. Carcea, M.; Sorto, M.; Batello, C.; Narducci, V.; Aguzzi, A.; Azzini, E.; Fantauzzi, P.; Finotti, E.; Gabrielli, P.; Galli, V.; Gambelli, L.; Maintha, K.M.; Namba, F.; Ruggeri, S.; Turfani, V. Nutritional characterization of traditional and improved dihé, alimentary blue-green algae from the lake Chad region in Africa. LWT Food Science and Technology 2015, 62, 753-763, http://dx.doi.org/10.1016/j.lwt.2014.10.039.

34. Batista, A.P.; Niccolai, A.; Fradinho, P.; Fragoso, S.; Bursic, I.; Rodolfi, L.; Biondi, N.; Tredici, M.R.; Sousa, I.; Raymundo, A. Microalgae biomass as an alternative ingredient in cookies: Sensory, physical and chemical properties, antioxidant activity and in vitro digestibility. Algal Research 2017, 26, 161-171, https://doi.org/10.1016/j.algal.2017.07.017.

35. Uribe-Wandurraga, Z.N.; Igual, M.; García-Segovia, P.; Martínez-Monzó, J. Effect of microalgae addition on mineral content, colour and mechanical properties of breadsticks. Food \& Function 2019, 10, 4685-4692, https://doi.org/10.1039/C9FO00286C.

36. Barkallah, M.; Dammak, M.; Louati, I.; Hentati, F.; Hadrich, B.; Mechichi, T.; Ayadi, M.A.; Fendri, I.; Attia, H.; Abdelkafi, S. Effect of Spirulina platensis fortification on physicochemical, textural, antioxidant and sensory properties of yogurt during fermentation and storage. LWT 2017, 84, 323-330, https://doi.org/10.1016/j.lwt.2017.05.071.

37. Rababah, T.; Aludatt, M.; Al-Mahasneh, M.; Gammoh, S.; Al-Obaidy, M.; Ajouly, T.; Bartkute-Norkūniene, $\mathrm{V}$. The effect of different fl our extraction rates on physiochemical and rheological characteristics. Bulg. J. Agric. Sci.2019,25, 581-588.

38. Cardone, G.; D’Incecco, P.; Casiraghi, M.C.; Marti, A. Exploiting Milling By-Products in Bread-Making: The Case of Sprouted Wheat. Foods 2020, 9, https://doi.org/10.3390/foods9030260.

39. Bolarinwa, I.F.; Oyesiji, O.O. Gluten free rice-soy pasta: proximate composition, textural properties and sensory attributes. Heliyon 2021, 7, https://doi.org/10.1016/j.heliyon.2021.e06052. 
40. Biernacka, B.; Dziki, D.; Gawlik-Dziki, U.; Różyło, R.; Siastała, M. Physical, sensorial, and antioxidant properties of common wheat pasta enriched with carob fiber. LWT 2017, 77, 186-192, https://doi.org/10.1016/j.lwt.2016.11.042.

41. Zen, C.K.; Tiepo, C.B.V.; da Silva, R.V.; Reinehr, C.O.; Gutkoski, L.C.; Oro, T.; Colla, L.M. Development of functional pasta with microencapsulated Spirulina: technological and sensorial effects. Journal of the Science of Food and Agriculture 2020, 100, 2018-2026, https://doi.org/10.1002/jsfa.10219.

42. Fois, S.; Piu, P.P.; Sanna, M.; Roggio, T.; Catzeddu, P. Starch digestibility and properties of fresh pasta made with semolina-based liquid sourdough. LWT 2018, 89, 496-502, https://doi.org/10.1016/j.lwt.2017.11.030.

43. Gull, A.; Prasad, K.; Kumar, P. Nutritional, antioxidant, microstructural and pasting properties of functional pasta. Journal of the Saudi Society of Agricultural Sciences 2018, 17, 147-153, https://doi.org/10.1016/j.jssas.2016.03.002.

44. Özyurt, G.; Uslu, L.; Yuvka, I.; Gökdoğan, S.; Atci, G.; Ak, B.; Işik, O. Evaluation of the Cooking Quality Characteristics of Pasta Enriched with Spirulina Platensis. Journal of Food Quality 2015, 38, 268-272, https://doi.org/10.1111/jfq.12142.

45. De Marco R., E.; Steffolani, M.E.; Martínez, C.S.; León, A.E. Effects of spirulina biomass on the technological and nutritional quality of bread wheat pasta. LWT - Food Science and Technology 2014, 58, 102-108,https://doi.org/10.1016/j.lwt.2014.02.054.

46. Raja, W.H.; Kumar, S.; Bhat, Z.F.; Kumar, P. Effect of ambient storage on the quality characteristics of aerobically packaged fish curls incorporated with different flours. SpringerPlus 2014, 3, https://doi.org/10.1186/2193-1801-3-106.

47. Jaworska, D.; Królak, M.; Przybylski, W.; Jezewska-Zychowicz, M. Acceptance of Fresh Pasta with $\beta$ Glucan Addition: Expected Versus Perceived Liking. Foods 2020, 9, https://doi.org/10.3390/foods9070869.

48. Yahfoufi, N.; Alsadi, N.; Jambi, M.; Matar, C. The Immunomodulatory and Anti-Inflammatory Role of Polyphenols. Nutrients 2018, 10,https://doi.org/10.3390/nu10111618.

49. de Marco Castro, E.; Shannon, E.; Abu-Ghannam, N. Effect of Fermentation on Enhancing the Nutraceutical Properties of Arthrospira platensis (Spirulina). Fermentation 2019, 5, https://doi.org/10.3390/fermentation5010028.

50. Finamore, A.; Palmery, M.; Bensehaila, S.; Peluso, I. Antioxidant, Immunomodulating, and MicrobialModulating Activities of the Sustainable and Ecofriendly Spirulina. Oxidative Medicine and Cellular Longevity 2017, 2017, https://doi.org/10.1155/2017/3247528.

51. Fradinho, P.; Niccolai, A.; Soares, R.; Rodolfi, L.; Biondi, N.; Tredici, M.R.; Sousa, I.; Raymundo, A. Effect of Arthrospira platensis (spirulina) incorporation on the rheological and bioactive properties of gluten-free fresh pasta. Algal Research 2020, 45,https://doi.org/10.1016/j.algal.2019.101743.

52. Aune, D. Plant Foods, Antioxidant Biomarkers, and the Risk of Cardiovascular Disease, Cancer, and Mortality: A Review of the Evidence. Advances in Nutrition 2019, 10, S404S421,https://doi.org/10.1093/advances/nmz042.

53. Seghiri, R.; Kharbach, M.; Essamri, A. Functional Composition, Nutritional Properties, and Biological Activities of Moroccan Spirulina Microalga. Journal of Food Quality 2019, 2019,https://doi.org/10.1155/2019/3707219.

54. Giannetti, V.; Boccacci Mariani, M.; Mannino, P.; Testani, E. Furosine and flavour compounds in durum wheat pasta produced under different manufacturing conditions: Multivariate chemometric characterization. LWT - Food Science and Technology 2014, 56, 15-20, https://doi.org/10.1016/j.lwt.2013.10.045.

55. Beleggia, R.; Platani, C.; Spano, G.; Monteleone, M.; Cattivelli, L. Metabolic profiling and analysis of volatile composition of durum wheat semolina and pasta. Journal of Cereal Science 2009, 49, 301-309, https://doi.org/10.1016/j.jcs.2008.12.002.

56. Pasqualone, A.; Paradiso, V.M.; Summo, C.; Caponio, F.; Gomes, T. Influence of Drying Conditions on Volatile Compounds of Pasta. Food and Bioprocess Technology 2014, 7, 719-731, https://doi.org/10.1007/s11947-013-1080-1.

57. Kermasha, S.; Van de Voort, F.R.; Metche, M. Changes in carbonyl compounds in the French bean as a function of cooking and enzyme treatment. J Agric Food Chem 1988, 36, 133137,https://doi.org/10.1021/jf00079a034.

58. Belitz, D.;Grosch, W.Qui'mica de los alimentos. Acribia, Zaragoza.Food Science and Technology International1998, 4, 212-212,https://doi.org/10.1177/108201329800400310.

59. Neff, E.; Frankel, N.;Selke, E.;Weisleder, D. Photosensitized oxidation of methyl linoleatemonohydroperoxides: hydroperoxy cyclic peroxides dehydroperoxides, keto esters and volatile thermal decomposition products. Lipids1983,18, 868-876.

60. Adamiec, J.; Rössner, J.; Velíšek, J.; Cejpek, K.; Šavel, J. Minor Strecker degradation products of phenylalanine and phenylglycine. European Food Research and Technology 2001, 212, 135-140, https://doi.org/10.1007/s002170000234.

61. Osada, Y.; Shibamoto, T. Antioxidative activity of volatile extracts from Maillard model systems. Food Chemistry 2006, 98, 522-528,https://doi.org/10.1016/j.foodchem.2005.05.084. 